\title{
Do negative events really have deteriorating effects on stock performance? A comparative study on Tesla (US) and Nio (China)
}

\author{
Yi Xuan Lim and Consilz Tan \\ Xiamen University - Malaysia, Sepang, Malaysia
}

\begin{abstract}
Purpose - Both investors and the stock markets are believed to behave in a perfectly rational manner, where investors focus on utility maximization and are not subjected to cognitive biases or any information processing errors. However, it has been discovered that the sentiment of the social mood has a significant impact on the stock market. This study aims to analyze how did the protest event of Tesla happened in April 2021 have a significant effect on the company's stock performance as well as its competitors, Nio, under the competitive effect.

Design/methodology/approach - The research is based on time series data collected from Tesla and Nio by employing 10 days, 15 days and 20 days anticipation and adjustment period for the event study. This study employed a text sentiment analysis to identify the polarity of the sentiment of the protest event using the Microsoft Azure machine learning tool which utilizes MPQA subjective lexicon.

Findings - The findings provide further evidence to show that a company-specific negative event has deteriorating effects on its stock performance, while having an opposite effect on its competitors.

Research limitations/implications - The paper argues that negative sentiments through social media word of mouth (SWOM) affect the stock market not just in the short run but potentially in the longer run. Such negative sentiments might create a snowball effect which causes the market to further scrutinize a company's operations and possibly lose confidence in the company.

Originality/value - This study explores how the Tesla's protest event at Shanghai Auto Show 2021 has a significant impact on Tesla's stock performance and prolonged negative impact although Tesla implemented immediate remedial actions. The remedial actions were not accepted positively and induced a wave of negative news which had a more persistent effect.
\end{abstract}

Keywords Stock market, Sentiment analysis, Event analysis, Social media word of mouth (SWOM),

Behavioral finance

Paper type Research paper

\section{Introduction}

Researchers of behavioral finance proposed that investors are not perfectly rational and make systematic errors due to emotions, social influence, self-deception and information processing errors (Statman, 2008). Psychologists validate those emotions which plays a significant role in the decision-making process, and this more so applies to individuals when making financial decisions, because it often involves more factors at stake, which stirs up the

\section{JEL Classification — G11, G12, O57}

(c) Yi Xuan Lim and Consilz Tan. Published in Journal of Asian Business and Economic Studies. Published by Emerald Publishing Limited. This article is published under the Creative Commons Attribution (CCBY 4.0) licence. Anyone may reproduce, distribute, translate and create derivative works of this article (for both commercial and non-commercial purposes), subject to full attribution to the original publication and authors. The full terms of this licence may be seen at http://creativecommons. org/licences/by/4.0/legalcode

The author acknowledges the contributions of two anonymous reviewers for their constructive comments and recommendation. The author thanks the Editor, Prof. Hoai Nguyen for his consideration and insightful comments.

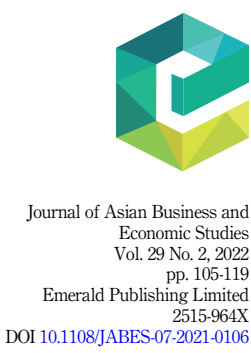


JABES

29,2

106

emotions of an individual even more (Baker and Nofsinger, 2010). Furthermore, the content of similar sentiment in the news media has the ability to influence stock price movements in similar directions (Schumaker et al., 2012). Lang et al. (2021) employed several HAR-RV-type models to verify that Internet information from Internet forums and the search engine could play a significant role in forecasting the volatility of the Chinese stock market.

A recent event that showed a clear depiction of behavioral finance is when the share price of Tesla Motors fell by almost $12 \%$ immediately after Elon Musk, the CEO of Tesla Motors, said that its share price seems "too high" in his social media (Bursztynsky, 2020). This shows that on top of the information presented, the emotional attributes attached to the information play an equally important role in influencing stock prices (Bollen et al., 2011). Tesla's stock price has been observed to greatly fluctuate whenever the CEO posts information that contains key information regarding the company; the CEO is also known for his active presence in social media, as well as frequently offering insights to the company's plans (Malhotra and Malhotra, 2016). This makes Tesla Motors the ideal case study for sentimental analysis of news and its effect on stock prices.

While there are a lot of competitors to Tesla's electric vehicle (EV), Nio Inc. is chosen for three reasons. First, it has the largest market capitalization in the US exchange market among its fellow Chinese based EV manufacturers that is also listed in the US exchange market (Nobanee et al., 2021; Liu, 2021); second, it is the product of one of the world's major economic leaders, China and lastly, because the event occurred in China, there would be a closer connection to its Chinese competitors as locals are more likely to shift from Tesla to local vehicles. This could greatly affect Tesla's sales performance on top of the fact that $30 \%$ of Tesla's sales come from China, there could be a potential drop in Tesla's sales and an increase in China-based EV manufacturers.

This study is important in identifying the impact of negative sentiment on a company's stock performance where event analysis will take place not just on the company itself but also on its competitors. To illustrate the framework for better understanding, this paper is structured as follows. Section 2 describes the literature review on behavioral finance, social mood, social media and online news platforms and competitive effect. Section 3 depicts the methodology of gathering and analyzing the data. Section 4 discusses event analysis and sentiment analysis. Finally, section 5 provides discussion and implications of the negative events on the stock performance and concludes the findings for the event study.

\section{Literature review}

Behavioral finance proposed that the financial market is less restrictive than traditional financial frameworks such as Von Neumann-Morgenstern's expected utility theory and arbitrage assumptions also often referred to as modern finance and is built on the EMH (Ritter, 2003). The cognitive aspects refer to the thought process and there is an abundant amount of psychology research documenting that humans make systematic errors during the thought process (Loewenstein et al., 2001).

When herding occurs, a substantial group of investors would trade with the same position at the same time, and this could occur when investors choose to forgo their current selfmarket assessment and choose to follow previous market trends (Avery and Zemsky, 1998). Overly reliance on financial analysts' predictions; mutual imitation among investors on the same securities, are among many other reasons (Sias, 2004). Herding has been widely acknowledged to be one of the main reasons to drive extreme market volatility and instability, which increases the fragility of our financial system (Spyrou, 2013). The disposition effect is a combination of two cognitive theories on behavioral finance, the prospect theory and mental accounting (Frazzini, 2006). This is a phenomenon where people tend to hold onto losses and 
seek to realize gains (Kaustia, 2010). It has been observed that the trading volume rises during a bullish market and falls during a bearish market (Byrne and Brooks, 2008).

\subsection{Social mood}

Social mood is a phenomenon where interaction among individuals will gradually have a strong influence on the whole society as a whole, leading to a shared sentiment and emotion (Prechter et al., 2012). Social mood is constantly shifting between positive and negative poles, the stronger the shared emotion is, the more apparent the social mood will be (Shu, 2010). When similar emotions or sentiments are shared across society, the level of optimism or pessimism could impact financial decisions and lead to market-wide occurrences (Shu, 2010). When the social mood is towards the positive side, investors are observed to be more willing to take on additional leverage to increase their investment, leading to a bullish market; contrastingly, when the social mood is towards the negative side, investors are observed to be more risk-averse, and the market becomes more volatile due to rising uncertainties (Nofsinger, 2005).

There have been several reports validating this phenomenon such as the work of Cutler et al. (1998), where they found that financial news covering macroeconomic performance explain one-third of stock volatility. Tetlock (2007) discovered that general financial news can predict stock prices for the short term to a certain extent. As more research studies are being done on behavioral finance, more evidence has surfaced to support the fact that emotions have a major influence over investment decisions (Schumaker et al., 2012). Investing in stock market is a high-stake activity and has the capabilities to arouse one's emotions, causing investors unable to stay rational at all times, and as a result, let their emotions take the wheels when making decisions (Li Q. et al., 2014). Bollen and Mao (2011) studied the predictability of "Twitter Mood" against stock market movements also showed that social mood was able to predict the short-term rise and falls of Dow Jones Industrial Average (DJIA) with a staggering direction accuracy of $86.7 \%$.

There is also empirical evidence proving that investors are affected by social mood transmitted through social media platforms and are affected through "social media word of mouth (SWOM)" (Nguyen et al., 2019). Positive SWOM sentiments were discovered to influence future earning aspects both in the short and long run, whereas negative SWOM sentiments were discovered to influence future earnings aspects in the short run only because companies will take measures to address such negative sentiments to eliminate any negative effects on the company (Kim et al., 2016). It has also been found that positive SWOM sentiments take longer time to impact the stock market because it is less impactful than negative SWOM sentiments (Balaji et al., 2016). In 2013, the AP's Twitter account was hacked, and the hacker(s) uploaded a tweet saying that two explosions had occurred in the White House and the president, Barack Obama had been injured. Within minutes, the value of the S\&P500 Index was reduced by approximately $\$ 136$ billion, and the DJIA fell by 143.5 points (Sharma and Panchadar, 2018).

\subsection{Social media and online news platforms}

People have employed new ways to share information and interact with others due to the advancement in digital technology and the rise of the Internet (Maragoudakis and Serpanos, 2016). People use social media as a platform to gain insights into the financial market as it is a platform where even professional investors, as well as traders and analysts, share their thoughts and findings (Bollen and Mao, 2011). As a result, non-professional investors use information posted on social media for self-evaluation and attempt to predict stock price movements, deduce social sentiment about market conditions and also share their thoughts and analysis (Corte, 2020). Some papers found social media to have no significant relationship
Deteriorating effects on stock performance 
JABES

29,2

108

with the stock market. Tumarkin and Whitelaw (2001) who studied the effect of Internet chat rooms on the stock market found the sentiment of the Internet chatrooms had no notable effect on the stock market. Das and Chen (2007) found no strong associations between the sentiment on Internet sharing forums and individual stocks. Quality measures have to be well-taken care of during the data collection phase, because there is a substantial group of people that uses social media platforms to intentionally promote spiteful ideologies, devalue products and services, which will decrease the credibility of the data (Li et al., 2014a, b).

Data acquired through financial news platforms are believed to be more reliable because information on such platforms is written by credible people with credible sources (Alanyali et al., 2013). However, one thing to note as suggested by the existing literature, is that when attempting to study news' effect on the stock market, one should conduct at the micro-level, meaning trying to study the effect of company-specific news on particular companies (Scheufele et al., 2011). It is much more difficult to study the relationship between news and the stock market as a complex connection between stock market stakeholders exists within the stock market (Tetlock, 2007). Moniz et al. (2011) also suggested that it is more appropriate for studies on news flow to identify short-term effects rather than the long-term. Mitra and Mitra (2011) argued that such studies only consider a one-way effect of media on the stock market, which has oversimplified the complex interaction between media and the stock market.

\subsection{Competitive event}

Several papers have identified that positive company-specific news will induce an upward movement in the company's stock price, generating positive abnormal returns (Hertzel et al., 2002; Graham, 2005). A company's specific positive news will also induce a downward movement on its competitors' stock prices, generating negative abnormal returns and is known as the competitive effect (Hsu et al., 2010). Fonseka et al. (2018) analyzed how private equity placement news of a company affected its competitors in the Chinese stock market. Their results were consistent with prior literature, as they found that the competitors of the company reported a negative cumulative abnormal return (CAR) during a 20 days event window of the event. On the other hand, the news induced a positive CAR for the underlying company itself during the 20 days event window of the event. Hsu et al. (2010) showed that not only the stock returns, but also the operating performance of the announcing company's competitors were adversely impacted when the IPO was first announced and once again when the IPO was completed.

What has been discussed so far implicates that a piece of company-specific news will affect the stock performance of the company. However, there are studies that showed the specific news will also affect the company's competitors.

\section{Outline of research design}

The selected cases are two EV manufacturers, Tesla and Nio, where the former is a US-based company, while the latter is a China-based company. Tesla is listed on Nasdaq, whereas Nio is listed on NYSE. On 19th April, a Chinese woman wearing a T-shirt with "The Brakes Don't Work" and "Invisible Killer" written on it, climbed on top of a Tesla vehicle at an auto show in Shanghai, in an attempt to protest against Tesla in response to the rising Tesla vehicle accidents (Moss, 2021). It had been discovered that the woman was involved in an accident with her Tesla vehicle earlier during the year, where she claimed that the accident occurred due to brake failures (Sun and Horwitz, 2021). Videos about the incident went viral on the Internet, criticizing Tesla's quality issues and their "insincere" apology. This incident was the beginning of a publicity disaster for Tesla, as a series of negative news would be released after the incident, invoking rigorous quality inspection and Chinese customer complaints. 


\subsection{Procedure}

First, this study identifies the sentiment of the event towards Tesla. Several news articles were retrieved from the online news websites, namely, Reuters, The Verge, Quartz, The Straits Time, The Star, South China Morning Post and Global Times, to perform a text sentiment analysis to identify the polarity of the sentiment. The sources of the news were from western and Chinese news platforms. The Microsoft Azure machine learning tool was employed as the text sentiment analyzer. The Microsoft Azure machine learning tool utilizes MPQA Subjective Lexicon, a generic dictionary that consists of 5,097 negative words and 2,533 positive words. Subsequently, daily closing prices are gathered to calculate the returns, expected returns and abnormal returns for Tesla and Nio. The daily closing prices between 1st of September 2020 until 28th of May 2021 of Tesla, Nio and Nasdaq Composite were obtained from Yahoo! Finance. Based on the information gathered, the anticipation and adjustment period will be determined. The anticipation period is a short period before the event date and the adjustment period is a short period after the event (Refer to Figure 1). The purpose for setting such periods is to capture any effect that either had taken effect before the event or taken effect after the event. The anticipation period is built upon the premise that the market has access to eventrelated information before the event, which, as a result, alters their decisions based on such information before the event (Prabhala, 1997). On the other hand, the adjustment period is built upon the premise that the market is not efficient and there is an existence of information lag, meaning and information of the event takes time to reach a significant portion of the market.

Fonseka et al. (2018) employed a 10 days anticipation and adjustment period for their event study. Hence, this paper employed 10 days anticipation and adjustment period as well, but on top of this, a 15 days and 20 days period will also be employed. The reason for this is because as aforementioned, the Tesla Protest event invoked a series of negative events for Tesla, such as the rise of customer complaints and videos of accidents related to Tesla vehicles; this condensed series of negative events continued to surface within 30 days after the event. Hence, the additional 15- and 20-days period was added to better capture the effect of the event itself, and the subsequent negative events that it invoked so that any significant relationship would not be left out. Finally, an estimation window consisting of 147 days, 142 days and 137 days prior to the beginning of the anticipation period will be used for the 10 days, 15 days and 20 days model, respectively.

\subsection{Variables}

There are three main variables used in this study to identify the effects of the event; actual returns (R), expected returns (ER) and abnormal returns (AR). In reference to the work of MacKinlay (1997), this study employed three different approaches to calculate the expected returns; the constant return approach, market return approach and market model approach. Three different approaches are employed because each approach captures different aspects of the stock market, thus, providing better insights into the stock market (Prabhala, 1997). The market return approach uses the selected market return as the expected return for Tesla and Nio, which for this case, will be the return of the Nasdaq Composite (^IXIC), since it is the US stock market where Tesla is listed on and also well known for housing stocks of tech giants (Hayes, 2021). The market model approach utilizes the following formula to calculate the expected return:
Deteriorating effects on stock performance

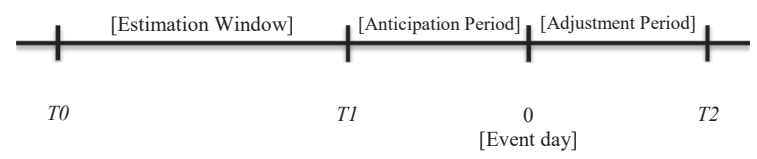

Figure 1.

Timeline for an event study 
JABES

29,2

$$
R_{i t}=\alpha_{i}+\beta_{i} R_{m t}+\varepsilon_{i t}
$$

where alpha measures the excess return of stock after being adjusted for random fluctuations and market volatility; beta measures the volatility of a stock in relation to the market portfolio.

The abnormal returns are derived by subtracting the actual returns of Tesla and Nio with the expected returns calculated through the three different methods mentioned above. Hence, both Tesla and Nio will have three different values for abnormal returns at any given time, $t_{i}$. The values of the abnormal return will, later on, be used to calculate the CAR and buy and hold abnormal returns (BHAR) of Tesla and Nio during the event day, anticipated period and an adjustment period. The CAR and BHAR values will be the key values that showcase whether the event has caused significant changes in stock performance (Chahine, 2004). The two measurements of abnormal return differ mainly by the way they sum up the abnormal returns of a period, as shown below, which captures the compounding effect of stock returns (Barber and Lyon, 1997).

$$
\begin{gathered}
\mathrm{CAR}_{i t}=\sum_{t=1}^{\tau} \mathrm{AR}_{i t} \\
\mathrm{BHAR}_{i t}=\prod_{t=1}^{\tau}\left[1+R_{i t}\right]-\prod_{t=1}^{\tau}\left[1+E\left(R_{i t}\right)\right]
\end{gathered}
$$

\subsection{Analysis method}

The event study methodology is commonly used among researchers in the finance and economics field, especially when tasked to measure effects related to the stock market and firm-related values (MacKinlay, 1997). Since this paper attempts to identify the effect of only one single event, the event study methodology would be a suitable approach and has higher odds in detecting any significant relationships (Strauss and Smith, 2019). The event study methodology begins by defining a set of normal values for the analysis variables (stock returns of Tesla and Nio) from a period prior to the event, otherwise known as the estimation window. The estimation window as suggested by MacKinlay (1997) should be approximately 120 days prior to the event, in order to get an appropriate estimate of the normal values for the analysis variables. After this, the normal values of the stock returns will be compared to those that are either during the event day or during a period close to the event day, in order to detect any significant changes caused by the event (Bartholdy et al., 2007). More specifically, the CAR and BHAR of Tesla and Nio's stocks will be employed to study against their respective normal returns in the estimation window. This paper compared the results across the three different approaches to calculate expected returns. This was done to have higher certainty in the results and deeper insights into the relationship between the abnormal returns and the normal return values.

\section{Analysis and results}

\subsection{Sentiment analysis on news collected}

Table 1 presents the protest incident that had an extremely negative sentiment. The Azure machine learning tool scales sentiment scores from 0 to 1 , where 0 is the most negative and 1 as the most positive. The average score for all six news articles collected was 0.001482 , indicating an extremely negative event for Tesla. 


\begin{tabular}{|c|c|c|c|c|}
\hline $\begin{array}{l}\text { Article } \\
\text { number }\end{array}$ & Article name & Sentiment & $\begin{array}{l}\text { Sentiment } \\
\text { score }\end{array}$ & \multirow{2}{*}{$\begin{array}{r}\text { Deteriorating } \\
\text { effects on stock } \\
\text { performance }\end{array}$} \\
\hline 1 & $\begin{array}{l}\text { AUTOSHOW Chinese woman's Tesla protest prompts 5-day } \\
\text { detention, company apology }\end{array}$ & Negative & $1.906265 \mathrm{E}-07$ & \\
\hline 2 & \multirow{3}{*}{$\begin{array}{l}\text { Woman detained for protesting Tesla at Shanghai auto show } \\
\text { Tesla stole the spotlight at China's premier auto show for all the } \\
\text { wrong reasons } \\
\text { Chinese woman who stormed Tesla display at car show } \\
\text { detained }\end{array}$} & Negative & 7.811359E-09 & \multirow{3}{*}{111} \\
\hline 3 & & Negative & $1.143272 \mathrm{E}-16$ & \\
\hline 4 & & Negative & $1.943413 \mathrm{E}-05$ & \\
\hline 5 & \multirow{3}{*}{$\begin{array}{l}\text { Chinese woman who stormed Tesla display at car show } \\
\text { detained for five days } \\
\text { Women protest quality issues involving Tesla vehicles at } \\
\text { Shanghai automobile fair }\end{array}$} & Negative & $1.445715 \mathrm{E}-05$ & \multirow{3}{*}{$\begin{array}{r}\text { Table 1. } \\
\text { Results of sentiment } \\
\text { analysis on news } \\
\text { collected }\end{array}$} \\
\hline 6 & & Negative & $8.858105 \mathrm{E}-03$ & \\
\hline Average & & Negative & $1.4820 E-03$ & \\
\hline
\end{tabular}

\subsection{Event study using 10 days window model}

Table 2 shows both CAR and BHAR of Tesla calculated by the three approaches went from positive during the anticipation period to negative during the adjustment period. The most drastic change would be the abnormal returns calculated through the constant return approach, where the CAR and BHAR of Tesla went from 8.9 to $8.6 \%$ to $-6.5 \%$ and $-6.8 \%$, respectively. The abnormal returns for this case deteriorated to almost $200 \%$ due to the event. Only the abnormal returns for the constant return approach on anticipation and adjustment periods were statistically significant. The BHAR calculated by all three approaches for the whole period were negative; whereas the CAR calculated by the constant return and market model approach for the whole period was negative, where only the market return approach yielded a positive abnormal return.

Table 3 shows the opposite result as it can be seen that Nio's CAR and BHAR values calculated by all three approaches went from negative during the anticipation period to

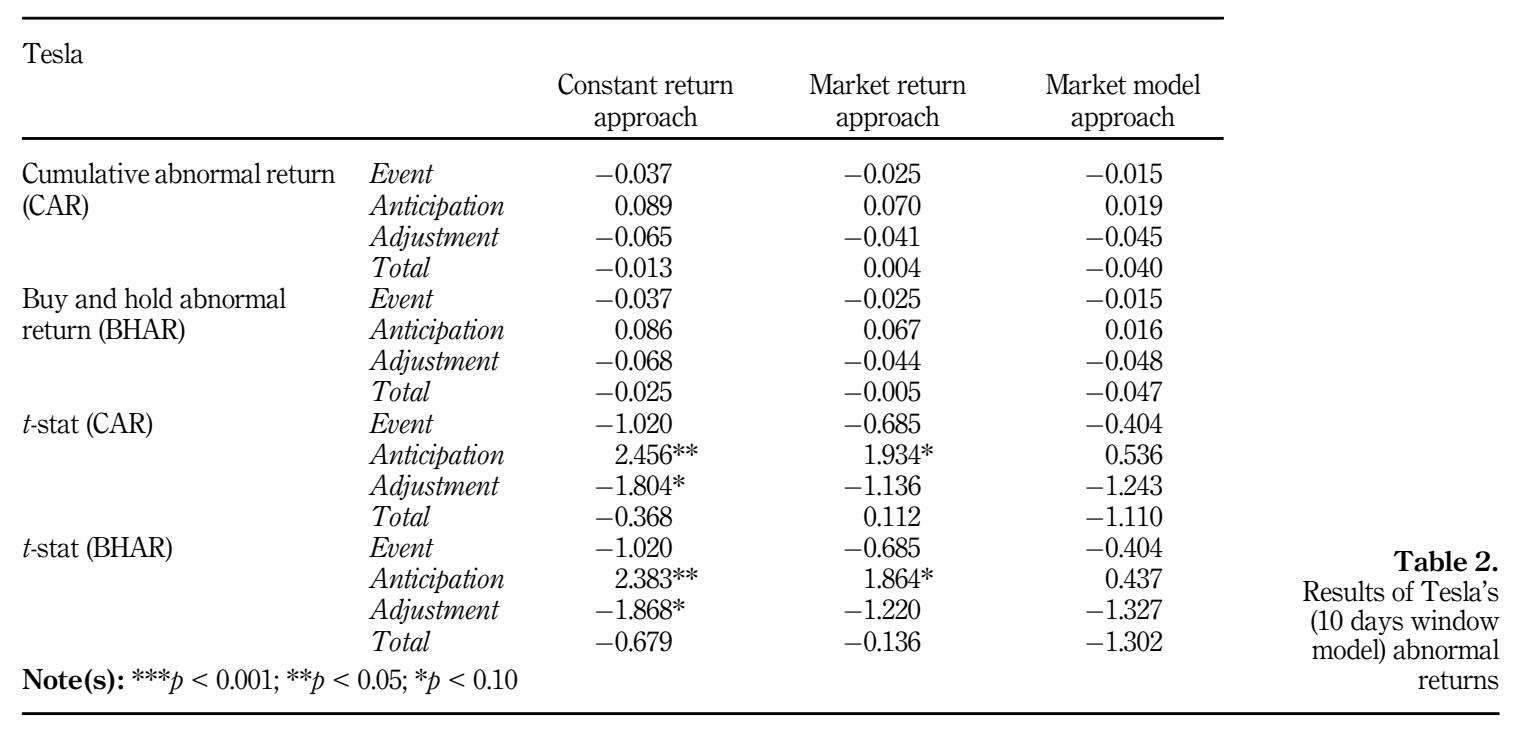


JABES

29,2

$t$-stat (BHAR)

Results of Nio's

(10 days window model) abnormal returns

\begin{tabular}{llccc}
\hline NIO & constant return & $\begin{array}{c}\text { Market return } \\
\text { approach }\end{array}$ & $\begin{array}{c}\text { Market model } \\
\text { approach }\end{array}$ \\
\hline Cumulative abnormal return & Event & 0.000 & 0.013 & 0.017 \\
(CAR) & Anticipation & -0.126 & -0.107 & -0.163 \\
& Adjustment & 0.027 & 0.060 & 0.028 \\
Buy and hold abnormal & Total & -0.099 & -0.033 & -0.117 \\
return (BHAR) & Event & 0.000 & 0.013 & 0.017 \\
& Anticipation & -0.124 & -0.107 & -0.157 \\
& Adjustment & 0.022 & 0.072 & 0.042 \\
$t$-stat (CAR) & Total & -0.105 & -0.043 & -0.121 \\
& Event & -0.010 & 0.279 & 0.363 \\
& Anticipation & $-2.623^{* *}$ & $-2.239 * *$ & $-3.406^{* * *}$ \\
$t$-stat (BHAR) & Adjustment & 0.560 & 1.263 & 0.591 \\
& Total & $-2.063 * *$ & -0.697 & $-2.451^{* *}$ \\
& Event & -0.010 & 0.279 & 0.363 \\
& Anticipation & $-2.591 * *$ & $-2.243 * *$ & $-3.276^{* * *}$ \\
Note(s): $* * * p$ & Adjustment & 0.460 & 1.499 & 0.884 \\
& Total & $-2.188^{* * *}$ & -0.904 & $-2.531^{* *}$ \\
& $* * p<0.05 ; * p<0.10$ & & & \\
\hline
\end{tabular}

positive during the event and adjustment period. Nio had a positive abnormal return on the event day itself as well. The abnormal returns on the event day and adjustment period were not statistically significant. Only the abnormal returns for the anticipation period were statistically significant.

\subsection{Event study using 15 Days window model}

Table 4 has a similar pattern as in Table 2 , where Tesla's CAR and BHAR values of Tesla calculated by all three approaches went from positive during the anticipation period to

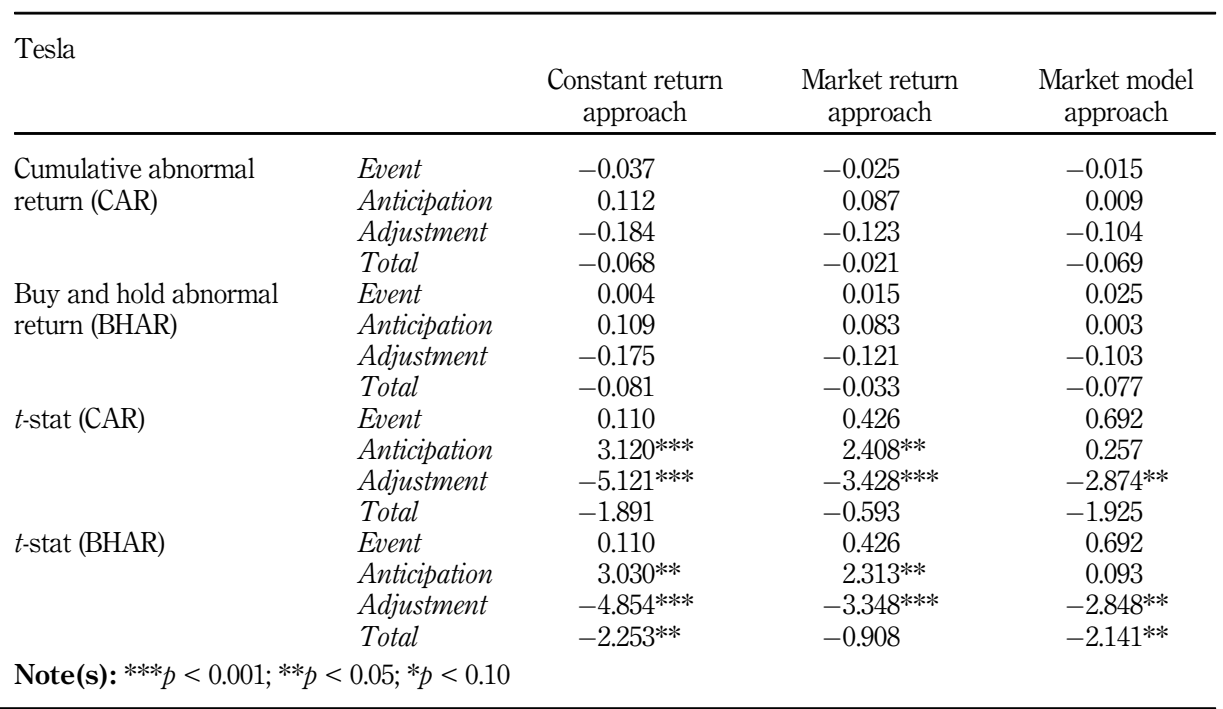

Note(s): ***p $<0.001 ; * p<0.05 ; * p<0.10$
Table 4.

Results of Tesla's (15 days window model) abnormal returns 
negative during the adjustment period. Both CAR and BHAR fell by more than $200 \%$ for all three approaches. The only difference this time is that both CAR and BHAR values of Tesla calculated by all three approaches during the adjustment period were statistically significant. The CAR and BHAR calculated by all three approaches for the whole period is observably negative as well, despite having positive abnormal returns for the anticipation period and event day. This means that the negative abnormal returns during the adjustment period are drastic enough to cause the abnormal returns for the whole period to be negative. The CAR and BHAR values calculated by the constant return and market return approach for the anticipation period were statistically significant, except for the market model approach.

Table 5 shows Nio's CAR and BHAR values were negative during both anticipation and adjustment period but were positive on the event day. Furthermore, it can be seen that while the abnormal returns were negative during the anticipation and adjustment period, only the abnormal returns calculated by the constant return approach deteriorated to more negative levels during the adjustment period. For instance, the CAR value calculated by the constant return approach went from $-5 \%$ to $-12.5 \%$, approximately $150 \%$ deterioration in abnormal returns. The abnormal returns calculated by the market return and market model approach were negative, where it had improved to fewer negative levels. For instance, the BHAR value calculated by the market model approach went from $-13.7 \%$ during the anticipation period to only $-6 \%$ during the adjustment period, an approximate $56 \%$ improvement in abnormal returns.

\subsection{Event study using 20 days window model}

Table 6 shows that only the market model approach showed a negative CAR and BHAR value during the anticipation period. Although the CAR and BHAR values calculated by the market model approach during the anticipation period were negative, it had worsened to even more negative levels during the adjustment period. For instance, the CAR calculated by the market model approach went from $-4 \%$ during the anticipation period, to $-16 \%$ during the adjustment period. Simultaneously, the BHAR calculated by the market model approach went from $-4.7 \%$ during the anticipation period to $-15.3 \%$ during the adjustment period.

\begin{tabular}{|c|c|c|c|c|}
\hline $\mathrm{NIO}$ & & $\begin{array}{l}\text { Constant return } \\
\text { approach }\end{array}$ & $\begin{array}{l}\text { Market return } \\
\text { approach }\end{array}$ & $\begin{array}{l}\text { Market model } \\
\text { approach }\end{array}$ \\
\hline \multirow{4}{*}{$\begin{array}{l}\text { Cumulative abnormal } \\
\text { return (CAR) }\end{array}$} & Event & 0.000 & 0.013 & 0.017 \\
\hline & Anticipation & -0.050 & -0.040 & -0.137 \\
\hline & Adjustment & -0.125 & -0.028 & -0.056 \\
\hline & Total & -0.175 & -0.054 & -0.176 \\
\hline \multirow{4}{*}{$\begin{array}{l}\text { Buy and hold abnormal } \\
\text { return (BHAR) }\end{array}$} & Event & 0.000 & 0.013 & 0.017 \\
\hline & Anticipation & -0.057 & -0.047 & -0.136 \\
\hline & Adjustment & -0.126 & -0.034 & -0.060 \\
\hline & Total & -0.176 & -0.067 & -0.174 \\
\hline \multirow[t]{4}{*}{$t$-stat (CAR) } & Event & -0.009 & 0.278 & 0.361 \\
\hline & Anticipation & -1.033 & -0.823 & $-2.850^{* *}$ \\
\hline & Adjustment & $-2.597 * * * *$ & -0.586 & -1.171 \\
\hline & Total & $-3.639 * * *$ & -1.131 & $-3.660 * * *$ \\
\hline \multirow[t]{4}{*}{$t$-stat (BHAR) } & Event & -0.009 & 0.278 & 0.361 \\
\hline & Anticipation & -1.184 & -0.971 & $-2.832^{* *}$ \\
\hline & Adjustment & $-2.623^{* * * *}$ & -0.708 & -1.247 \\
\hline & Total & $-3.665^{* * *}$ & -1.391 & $-3.616^{* * * *}$ \\
\hline
\end{tabular}

Deteriorating effects on stock performance

Note(s): ***p $<0.001 ; * * p<0.05 ; *^{*}<0.10$ 


\section{JABES \\ 29,2}

\begin{tabular}{llccc}
\hline Tesla & Constant return & $\begin{array}{c}\text { Market return } \\
\text { approach }\end{array}$ & $\begin{array}{c}\text { Market model } \\
\text { approach }\end{array}$ \\
\hline Cumulative abnormal & Event & -0.037 & -0.025 & -0.015 \\
return (CAR) & Anticipation & 0.041 & 0.036 & -0.040 \\
& Adjustment & -0.265 & -0.183 & -0.160 \\
& Total & -0.221 & -0.132 & -0.175 \\
Buy and hold abnormal & Event & 0.004 & 0.015 & 0.025 \\
return (BHAR) & Anticipation & 0.030 & 0.028 & -0.047 \\
& Adjustment & -0.241 & -0.172 & -0.153 \\
& Total & -0.215 & -0.136 & -0.173 \\
-stat (CAR) & Event & 0.102 & 0.419 & 0.682 \\
& Anticipation & 1.106 & 0.976 & -1.089 \\
& Adjustment & $-7.244^{* * *}$ & $-4.993^{* * * *}$ & $-4.369^{* * *}$ \\
& Total & $-6.036^{* * *}$ & $-3.597^{* * * *}$ & $-4.777^{* * * *}$ \\
$t$-stat (BHAR) & Event & 0.102 & 0.419 & 0.682 \\
& Anticipation & 0.811 & 0.756 & -1.278 \\
& Adjustment & $-6.576^{* * * *}$ & $-4.704^{* * * *}$ & $-4.184^{* * * *}$ \\
& Total & $-5.881^{* * *}$ & $-3.721^{* * * *}$ & $-4.716^{* * * *}$ \\
Note(s): *** $p<0.001 ; * * p<0.05 ; * p<0.10$ & & & \\
\hline
\end{tabular}

Table 6.

Results of Tesla's (20 days window model) abnormal returns
Alongside with the CAR and BHAR calculated by the constant return and market return approaches, it can be seen that the abnormal returns of Tesla had deteriorated after the event occurred. The result also shows that abnormal returns of Tesla calculated by all three approaches for the whole period were negative and statistically significant. Given the fact that the abnormal returns were mostly positive during the anticipation period, the deterioration of abnormal returns were drastic enough to cause the abnormal returns for the whole period to be negative. This shows that the event as a whole had a significant impact on Tesla's stock performance and also shows that the negative news harmed Tesla's stock performance during the 20 days window.

The results in Table 7 were similar to those in Table 5 , where Nio's CAR and BHAR values remained at negative territories during the adjustment period. However, it can be observed that although the CAR and BHAR values were still at negative territories, they were notably less negative compared to the anticipation period, showing that there is an improvement in Nio's stock performance during the adjustment period. It can be seen that the CAR and BHAR values calculated by all three approaches for the whole period were negative and also statistically significant.

The results showed that the negative event of Tesla caused the abnormal returns of Tesla to deteriorate during the adjustment period, which is after the event. An identical phenomenon occurs for both Tesla and Nio, that is the longer the duration of the window, the more statistically significant the abnormal returns. Furthermore, the abnormal return values for both Tesla and Nio were more in line with expectations the longer the window is. What this entails is that the longer the period after the event, the more apparent the effect of the event manifests onto Tesla and Nio's stock performance.

\section{Discussion and conclusion}

\subsection{Discussion}

Existing literature has shown that social mood and news significantly influence the stock market and have predictive qualities to a certain extent (Shu, 2010; Prechter et al., 2012; Scheufele et al., 2011; Tetlock, 2007). This paper further provides evidence to support the 


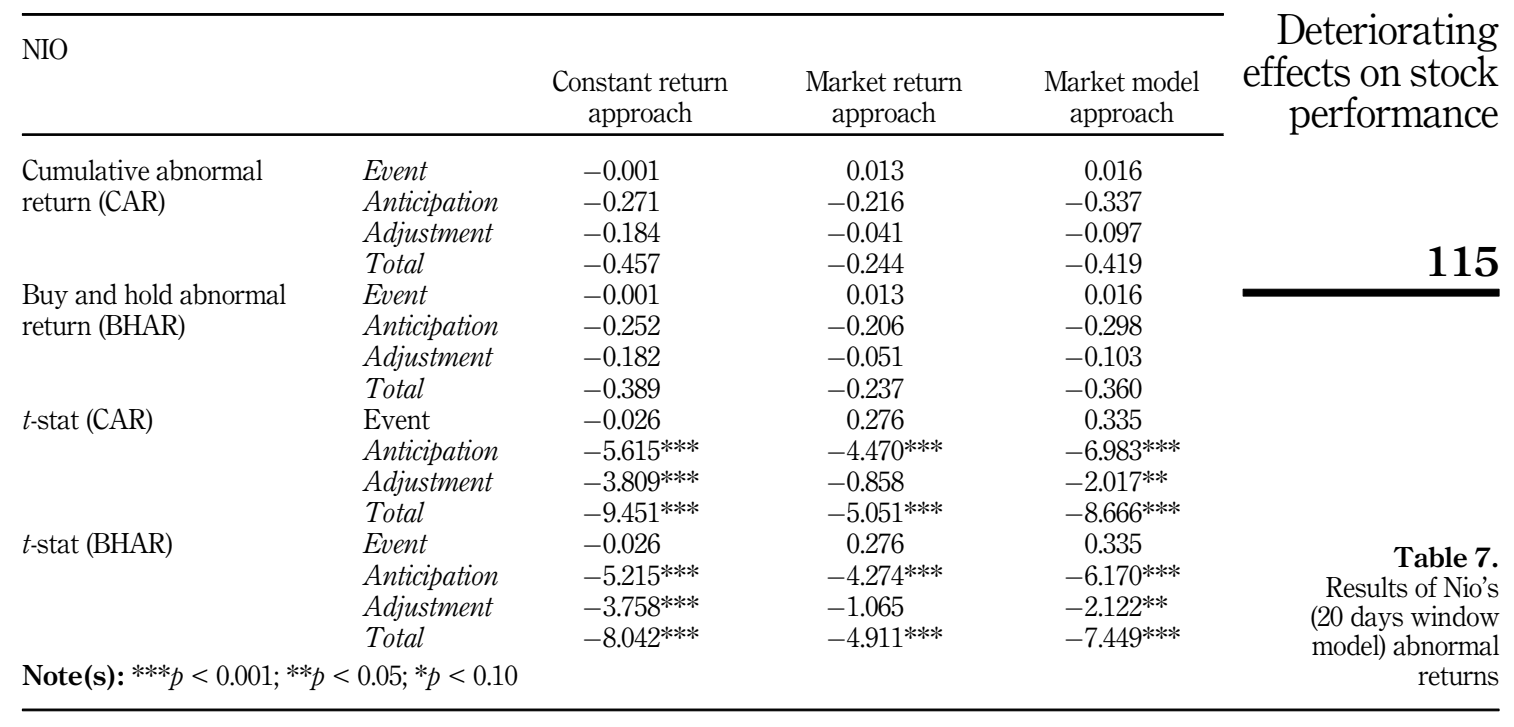

above statement and argues that by studying the effects of social mood and news at the micro-level, one will be able to discover more significant insights into the financial market. The findings showed that negative news also has a competitive effect, but instead of deteriorating competitors' stock performance, negative news of a company will improve the stock performance of its competitors. Nio was chosen as the competitor to be studied because the event studied occurred in China, which has a more significant connection to the event given that it is a fellow EV manufacturer but based in China. By reflecting on the work of Mitra and Mitra (2011), and Moniz et al. (2011), where they suggested on studying the effects of social mood and news on the stock market at the micro-level, this paper has studied specifically on the effect of a company-specific news on the underlying company and its competitor which has close connections to.

Based on the analysis, in the 20 days window model, Tesla's abnormal returns turned from positive to negative during the adjustment period. During the adjustment period, the abnormal returns of Tesla deteriorated to double-digit negative levels; it deteriorated by as much as $-26.5 \%$. Adding on, the abnormal returns for the whole period also turned out to be negative, which indicates that the event as a whole, had a negative impact on Tesla's stock performance. At the same time, the 20 days window model for Nio also showed results that were in line with expectations and statistically significant. Nio's abnormal returns had improved in the sense that it was less negative during the adjustment period as compared to the anticipation period.

After the incident, Tesla immediately apologized to the public regarding the safety concerns of its autonomous driving function, and fast forward to 4 weeks after the event, Tesla announced that the data collected from Chinese Tesla vehicles will be stored in China and no longer in the US (Global Times, 2021b). However, despite such attempts by Tesla, the Chinese citizens were not particularly keen on Tesla's apologies and even accused Tesla of being insincere for their apologies (O'Kane, 2021). This, in fact, gave rise to a wave of negative news regarding Tesla for weeks after the event (Global Times, 2021a). This could be one of the reasons for having results that are more significant and in line with expectations as the window length increased, because the 20 days window model was able to better capture 
JABES

29,2

the negative effects of subsequent news than the 10 days and 15 days model since it covered a longer period of time. This particular finding argues that negative sentiments SWOM affect the stock market not just in the short run, but potentially in the long run as well.

\subsection{Limitations and recommendations}

Though there were significant findings and sufficient evidence to support that social mood sentiment affects stock movement, as well as the protest event, has an impact on Tesla's and Nio's stock performance, there were differences in the results across the three models of different window lengths. During the 10 days window, although the abnormal returns for both Tesla and Nio responded to the event as expected, they were not statistically significant to support the hypotheses. For the 15 days window, on the other hand, only Tesla's abnormal returns for the adjustment period were statistically significant. This has in fact contradict with the findings of Nguyen et al. (2019), where they find that the effect of negative social mood and news only lasts for the short term, as companies would immediately take remedial actions to eliminate any negative effects on the company.

While there is sufficient evidence in proving that the protest event had a significant impact on Tesla and Nio's stock performance, however, be premature to conclude that the competitive effect exists for company-specific news. It is because this research only included one competitor of Tesla, but Tesla has more than one competitor in China. To truly conclude that the competitive effect exists, future research could include more competing companies to study the existence of the competitive effect. Besides, companies in related industries such as the new energy industry shall be included in such a study to better understand the impact of the competitive effect.

\subsection{Conclusion}

It is evident that the protest event and news of this event had a significant impact on Tesla's stock performance, as the abnormal returns of Tesla after the event notably deteriorated. The sentiment of the news about the event was found to be extremely negative, this once again validates that the sentiment of social mood affects the stock performance. The protest event had a positive effect on Nio's stock performance, where Nio's stock performance was seen to improve within a 20 days window after the event. These findings echo with the research of Hsu et al. (2010) and Fonseka et al. (2018), where they found the sentiment of company-specific news positively affects the stock performance of the underlying company while negatively affecting the stock performance of the competing companies. All in all, the findings of this paper provide evidence that company-specific news does not only affect the underlying company itself but also inversely affects its competitors.

\section{References}

Alanyali, M., Moat, H.S. and Preis, T. (2013), "Quantifying the relationship between financial news and the stock market”, Scientific Reports, Vol. 3 No. 1, pp. 1-6, doi: 10.1038/srep03578.

Avery, C. and Zemsky, P. (1998), "Multidimensional uncertainty and herd behavior in financial markets", The American Economic Review, Vol. 88 No. 4, pp. 724-748, available at: https://www. jstor.org/stable/117003z.

Baker, H.K. and Nofsinger, J.R. (2010), "Behavioral finance: an overview", Baker, H.K. and Nofsinger, J.R. (Eds), Behavioral Finance: Investors, Corporations, and Markets, John Wiley \& Sons, Hoboken, New Jerssey, NJ, pp. 3-21.

Balaji, M.S., Khong, K.W. and Chong, A.Y.L. (2016), "Determinants of negative word-of-mouth communication using social networking sites", Information and Management, Vol. 53 No. 4, pp. 528-540, doi: 10.1016/j.im.2015.12.002. 
Barber, B.M. and Lyon, J.D. (1997), "Detecting long-run abnormal stock returns: the empirical power and specification of test statistics", Journal of Financial Economics, Vol. 43 No. 3, pp. 341-372, doi: 10.1016/s0304-405x(96)00890-2.

Bartholdy, J., Olson, D. and Peare, P. (2007), "Conducting event studies on a small stock exchange", The European Journal of Finance, Vol. 13 No. 3, pp. 227-252, doi: 10.1080/13518470600880176.

Bollen, J. and Mao, H. (2011), "Twitter mood as a stock market predictor", Computer, Vol. 44 No. 10, pp. 91-94, doi: 10.1109/mc.2011.323.

Bollen, J., Mao, H. and Zeng, X. (2011), "Twitter mood predicts the stock market”, Journal of Computational Science, Vol. 2 No. 1, pp. 1-8, doi: 10.1016/j.jocs.2010.12.007.

Bursztynsky, J. (2020), "Tesla shares tank after Elon Musk tweets the stock price is too high", available at: https://www.cnbc.com/2020/05/01/tesla-ceo-elon-musk-says-stock-price-is-too-highshares-fall.html (accessed 30 June 2021).

Byrne, A. and Brooks, B. (2008), Behavioral Finance: Theories and Evidence, The Research Foundation of CFA Institute Literature Review, available at: https://citeseerx.ist.psu.edu/viewdoc/ download?doi=10.1.1.471.3672\&rep $=$ rep1\&type $=$ pdf.

Chahine, S. (2004), "Long-run abnormal return after IPOs and optimistic analysts' forecasts", International Review of Financial Analysis, Vol. 13 No. 1, pp. 83-103, doi: 10.1016/j.irfa.2004.01.004.

Corte, M. (2020), How Social Media Usage by Managers Affects Corporate Value: The Case of Elon Musk, (Unpublished master's thesis), Universidade Católica Portuguesa, Lisbon, Portugal, available at: https://repositorio.ucp.pt/bitstream/10400.14/31326/1/152418069_Miguel\% 20Corte_PDFA.pdf.

Cutler, D.M., Poterba, J.M. and Summers, L.H. (1988), What Moves Stock Prices?, Working Paper w2538, National Bureau of Economic Research, Cambridge, Massachusetts.

Das, S.R. and Chen, M.Y. (2007), "Yahoo! for Amazon: sentiment extraction from small talk on the web”, Management Science, Vol. 53 No. 9, pp. 1375-1388.

Fonseka, M.M., Rajapakse, R.L. and Tian, G.L. (2018), "Competitors' stock price reactions in response to private equity placements: evidence from a transitional economy", [Electronic version], Economic Research-Ekonomska istraživanja, Vol. 31 No. 1, pp. 550-575.

Frazzini, A. (2006), "The disposition effect and underreaction to news", The Journal of Finance, Vol. 61 No. 4, pp. 2017-2046, doi: 10.1111/j.1540-6261.2006.00896.x.

Global Times (2021a), "GT voice: Tesla's PR crisis leads to scrutiny of its quality", Global Times, available at: https://www.globaltimes.cn/page/202104/1222369.shtml (accessed 30 June 2021).

Global Times (2021b), "Tesla announces to store all data collected by its cars within China", Global Times, available at: https://www.globaltimes.cn/page/202105/1224466.shtml (accessed 30 June 2021).

Graham, J.E. (2005), "Equity private placements, liquid assets, and firm value", Journal of Economics and Finance, Vol. 29 No. 3, pp. 321-336, doi: 10.1007/bf02761578.

Hayes, A. (2021), "Nasdaq", available at: https://www.investopedia.com/terms/n/nasdaq.asp (accessed 30 June 2021).

Hertzel, M., Lemmon, M., Linck, J.S. and Rees, L. (2002), "Long-run performance following private placements of equity", The Journal of Finance, Vol. 57 No. 6, pp. 2595-2617, doi: 10.1111/15406261.00507.

Hsu, H.C., Reed, A.V. and Rocholl, J. (2010), "The new game in town: competitive effects of IPOs", The Journal of Finance, Vol. 65 No. 2, pp. 495-528, doi: 10.1111/j.1540-6261.2009.01542.x.

Kaustia, M. (2010), "Disposition effect”, Behavioral Finance, Vol. 6, pp. 169-189, doi: 10.1002/ 9781118258415.

Kim, S.J., Wang, R.J.H., Maslowska, E. and Malthouse, E.C. (2016), "Understanding a fury in your words: the effects of posting and viewing electronic negative word-of-mouth on purchase behaviors", Computers in Human Behavior, Vol. 54, pp. 511-521, doi: 10.1016/j.chb.2015.08.015.
Deteriorating effects on stock performance 
JABES

29,2

Lang, Q., Wang, J., Ma, F., Huang, D. and Mohamed Ismail, M.W. (2021), "Is Baidu index really powerful to predict the Chinese stock market volatility? New evidence from the internet information", China Finance Review International, Vol. ahead-of-print No. ahead-of-print, doi: 10. 1108/CFRI-03-2021-0047.

Li, H., Mukherjee, A., Liu, B., Kornfield, R. and Emery, S. (2014a), "Detecting campaign promoters on twitter using Markov random fields", IEEE International Conference on Data Mining, pp. 1550-4786, doi: 10.1109/icdm.2014.59.

Li, Q., Wang, T., Li, P., Liu, L., Gong, Q. and Chen, Y. (2014b), "The effect of news and public mood on stock movements", Information Sciences, Vol. 278, pp. 826-840, doi: 10.1016/j.ins.2014.03.096.

Liu, S. (2021), "Competition and valuation: a case study of Tesla Motors", IOP Conference Series: Earth and Environmental Science, IOP Publishing, Vol. 692 No. 2, p. 022103.

Loewenstein, G.F., Weber, E.U., Hsee, C.K. and Welch, N. (2001), "Risk as feelings", Psychological Bulletin, Vol. 127 No. 2, pp. 267-286, doi: 10.1037/0033-2909.127.2.267.

MacKinlay, A.C. (1997), "Event studies in economics and finance", Journal of Economic Literature, Vol. 35 No. 1, pp. 13-39, doi: 10.2307/2729691.

Malhotra, C.K. and Malhotra, A. (2016), "How CEOs can leverage Twitter", MIT Sloan Management Review, Vol. 57 No. 2, pp. 73-79, available at: http://ilp.mit.edu/media/news_articles/smr/2016/ 57203.pdf.

Maragoudakis, M. and Serpanos, D. (2016), "Exploiting financial news and social media opinions for stock market analysis using mcmc bayesian inference", Computational Economics, Vol. 47 No. 4, pp. 589-622, doi: 10.1007/s10614-015-9492-9.

Mitra, G. and Mitra, L. (2011), The Handbook of News Analytics in Finance, John Wiley \& Sons, Vol. 596, doi: 10.1002/9781118467411.

Moniz, A., Brar, G., Davies and Strudwick, A. (2011), "The impact of news flow on asset returns: an empirical study", The Handbook of News Analytics in Finance, Vol. 596, pp. 211-228, doi: 10. 1002/9781118467411.

Moss, T. (2021), "Tesla faces new China test after woman's auto-show protest goes viral", The Wall Street Journal, available at: https://www.wsj.com/articles/tesla-faces-new-china-challenge-afterwomans-auto-show-protest-goes-viral-11618835609 (accessed 29 June 2021).

Nguyen, H., Calantone, R. and Krishnan, R. (2019), "Influence of social media emotional word of mouth on institutional investors' decisions and firm value", Management Science. doi: 10.1287/mnsc. 2018.3226.

Nobanee, H., Alzaabi, H., Alremeithi, A., Abdulla, M., Azim, D. and Ismaili, N. (2021), Working Capital Management Ratios: A Comparative Study between Tesla and Nio, (Unpublished academic exercise), Abu Dhabi University, Abu Dhabi, available at: SSRN 3763482 https://poseidon01. ssrn.com/delivery.php? $\mathrm{ID}=96000511306706500608211909512110910905908900000808909209$ 912111402709702009812609612703001111501502103904500611502500202108910904502004006 006510009209209700512512409400805909508406702606412106500412211902403107212102812 $3006110125107002010116072101119024 \& \mathrm{EXT}=$ pdf $\&$ INDEX $=$ TRUE.

Nofsinger, J.R. (2005), "Social mood and financial economics", Journal of Behavioral Finance, Vol. 6 No. 3, pp. 144-160, doi: 10.1207/s15427579jpfm0603_4.

O'Kane, S. (2021), "Woman detained for protesting Tesla at Shanghai auto show", The Verge, available at: https://www.theverge.com/2021/4/20/22394638/tesla-shanghai-auto-show-protestbrake-failure (accessed 29 June 2021).

Prabhala, N.R. (1997), "Conditional methods in event studies and an equilibrium justification for standard event-study procedures", Review of Financial Studies, Vol. 10 No. 1, pp. 1-38, doi: 10.1093/rfs/10.1.1.

Prechter, R.R., Goel, D., Parker, W.D. and Lampert, M. (2012), "Social mood, stock market performance, and U.S. presidential elections”, SAGE Open, Vol. 2 No. 4, doi: 10.1177/2158244012459194.

Ritter, J.R. (2003), "Behavioral finance”, Pacific-Basin Finance Journal, Vol. 11 No. 4, pp. 429-437, doi: 10.1016/s0927-538x(03)00048-9. 
Scheufele, B., Haas, A. and Brosius, H.B. (2011), "Mirror or molder? A study of media coverage, stock prices, and trading volumes in Germany", Journal of Communication, Vol. 61 No. 1, pp. 48-70.

Schumaker, R.P., Zhang, Y., Huang, C.N. and Chen, H. (2012), "Evaluating sentiment in financial news articles", Decision Support Systems, Vol. 53 No. 3, pp. 458-464, doi: 10.1016/j.dss.2012.03.001.

Sharma, V. and Panchadar, A. (2018), "Tesla shares reel as executives quit and CEO smokes pot on webcast", Reuters, available at: https:/www.reuters.com/article/us-teslamoves/tesla-shares-reelas-executives-quit-and-ceo-smokes-pot-on-webcastidUSKCN1LN1MH (accessed 29 June 2021).

Shu, H.C. (2010), "Investor mood and financial markets", Journal of Economic Behavior and Organization, Vol. 76 No. 2, pp. 267-282, doi: 10.1016/j.jebo.2010.06.004.

Sias, R.W. (2004), "Institutional herding”, Review of Financial Studies, Vol. 17 No. 1, pp. 165-206, doi: $10.1093 / \mathrm{rfs} / \mathrm{hhg} 035$.

Spyrou, S. (2013), "Herding in financial markets: a review of the literature", Review of Behavioural Finance, Vol. 5 No. 2, pp. 175-194, doi: 10.1108/rbf-02-2013-0009.

Statman, M. (2008), “What is behavioral finance?”, Handbook of Finance, John Wiley \& Sons, Vol. 2, Chapter 9. doi: 10.1002/9780470404324.hof002009.

Strauss, N. and Smith, C.H. (2019), "Buying on rumors: how financial news flows affect the share price of Tesla", Corporate Communications: An International Journal, Vol. 24 No. 4, pp. 593-607, doi: 10.1108/CCIJ-09-2018-0091.

Sun, Y. and Horwitz, J. (2021), “Autoshow Chinese woman's tesla protest prompts 5-day detention, company apology", Reuters, available at: https:/www.reuters.com/world/china/autoshowchinese-woman-who-stormed-tesla-display-car-show-detained-5-days-2021-04-20/ (accessed 28 June 2021).

Tetlock, P.C. (2007), "Giving content to investor sentiment: the role of media in the stock market", The Journal of Finance, Vol. 62 No. 3, pp. 1139-1168, doi: 10.1111/j.1540-6261.2007.01232.x.

Tumarkin, R. and Whitelaw, R.F. (2001), "News or noise? Internet postings and stock prices", Financial Analysts Journal, Vol. 57 No. 3, pp. 41-51.

\section{Further reading}

Griffith, J., Najand, M. and Shen, J. (2019), "Emotions in the stock market", Journal of Behavioral Finance, Vol. 21 No. 1, pp. 1-5, doi: 10.1080/15427560.2019.1588275.

\section{Corresponding author}

Consilz Tan can be contacted at: tanconsilz@gmail.com

For instructions on how to order reprints of this article, please visit our website:

www.emeraldgrouppublishing.com/licensing/reprints.htm

Or contact us for further details: permissions@emeraldinsight.com 